\title{
Postharvest Handling of Cut Gloriosa rothschildiana O'Brien (Liliaceae) Flowers
}

\author{
Rodney B. Jones ${ }^{1}$ and Janyce K. Truett \\ Institute of Plant Sciences, Knoxfield, Victorian Department of Agriculture, P. O. Box 174, Ferntree \\ Gully, Victoria 3156, Australia \\ Additional index words. flame lily, cold storage, ethylene, sucrose treatment
}

\begin{abstract}
Postharvest treatments designed to enhance the vase life of cut Gloriosa rothschildiana flowers were tested. Vase life was significantly extended by the germicides 8 -HQC $\left(250 \mathrm{mg} \cdot \mathrm{liter}^{-1}\right)$, DICA $\left(50 \mathrm{mg} \cdot \mathrm{liter}^{-1}\right)$, and Physan-20 (50 $\left.\mathrm{mg} \cdot \mathrm{liter}^{-1}\right)$. Germicides acted primarily by improving solution uptake. Sucrose, either as a continuous treatment (of $2 \%$ or $5 \% \mathrm{w} / \mathrm{v}$ ), or as a 24 -hour pulse $(20 \%)$, significantly enhanced vase life, primarily by enhancing the development of immature buds and delaying senescence in open flowers. Flowers stored at 1C developed signs of chilling injury within 3 days, but chilling symptoms were not displayed in stems stored at $10 \mathrm{C}$ for 10 days. Flowers were not affected when exposed to $50 \mu$ ethylene/liter for 24 hours. Transport and short-term storage in sealed, airfilled bags to protect the flowers from physical damage resulted in some atmosphere modification within the bags. Fungal growth occurred when flowers were kept in air-tilled bags for more than 6 days, resulting in a reduction in vase life. Chemical names used: 8-hydroxyquinoline citrate (8-HQC); sodium dichloroisocyanuric acid (DICA); n-alkyl dimethyl ethylbenzyl ammonium chloride (Phyrsan-20).
\end{abstract}

Gloriosa rothschildiana is a tuberous, climbing plant native to Zimbabwe that produces brilliantly colored red and orangeyellow flowers 7 to $10 \mathrm{~cm}$ in diameter. The flowers are notable for the manner in which the petals invert $180^{\circ}$ during development, leading to the common name of "inside-out flower." Recently, the Gloriosa lily has become popular as a cut flower on the Australian and Japanese markets. The postharvest information that is available on Gloriosa is incomplete and contains misleading information on storage conditions, including recommendations for storing at low (1C) temperature (Holstead, 1985; Sacalis, 1989; Vaughan, 1988). This paper provides detailed information on the optimal germicide, sucrose concentration, storage temperature requirements for, and ethylene sensitivity of $\mathrm{G}$. rothschildiana.

\section{Materials and Methods}

Plant material. Gloriosa rothschildiana stems consist of two fully open flowers and three to five developing buds (Fig. 1). Leaves are typically dark green and glossy, ending in tendrils. Immature buds are green, with the petals hanging down vertically. As the flower develops, the petals expand and reflex, so that at full maturity they have reflexed $180^{\circ}$. Mature flowers vary from 8 to $12 \mathrm{~cm}$ in diameter and consist of six narrow red petals with curled yellow margins curving upwards. Senescent flowers are -faded, with the petals falling into a more horizontal position.

Stems $\approx 1 \mathrm{~m}$ long were harvested from a commercial grower and transported, with the cut ends in water, to the laboratory within $1 \mathrm{~h}$ of harvest. Complete stems, individual detached open flowers, or immature buds were used in experiments as indicated. Individual flowers are often used in arrangements and have a similar vase life if attached to the stem or detached (R. B. J., unpublished data). Five replicates were randomly as-

Received for publication 5 Aug. 1991. Accepted for publication 13 Jan. 1992. We thank Nico van Rooyen, of Gloriosa Nursery Pty. Ltd., Emerald, Victoria, for supplying the flowers used in this study. Thanks also to John Faragher and Kevin Clayton-Greene for help in the preparation of this manuscript, and Peter Franz for statistical advice. The cost of publishing this paper was defrayed in part by the payment of page charges. Under postal regolationa, this paper therefore must be hereby marked advertisement solely to indicate this fact.

'To whom reprint requests should be sent. signed to each treatment and were sealed in test tubes with parafilm. Flowers.and solutions were weighed every day to determine fresh weight (FW) and solution uptake. Solutions were changed every 3 days to guard against breakdown of active constituents (Halevy and Mayak, 1981).

Vase life was assessed daily under constant conditions: $20 \mathrm{C}$ $\pm 1 \mathrm{C}, 65 \% \pm 5 \%$ relative humidity $(\mathrm{RH})$, and $24 \mathrm{~h}$ light at an intensity of $10 \mu \mathrm{mol} \cdot \mathrm{m}^{-2} \cdot \mathrm{s}^{-1}$ Vase life was considered terminated when petal edges wilted or curled, faded in color, or when blackening was detected around the perianth. Vase life of complete stems was considered terminated when $>50 \%$ of flowers displayed the senescent symptoms described.

Germicides. Open flowers were set in solutions containing $50 \mathrm{mg}$ DICA/liter, 1-bromo-3-chloro-5,5-dimethylhydantoin (BCDMH at $5 \mathrm{mg} \cdot$ liter $^{-1}$ available chlorine), $250 \mathrm{mg}$ benzalkonium chloride $(\mathrm{BChl}) / \mathrm{liter}, 250 \mathrm{mg} 8-\mathrm{HQC} / \mathrm{liter}$, or $50 \mathrm{mg}$ Physan-20/liter, with distilled water as a control. The $\mathrm{pH}$ of each germicide solution was measured at the start of each experiment. FW and solution uptake were measured daily until the end of vase life.

Sucrose treatments. Continuous sucrose treatments were applied to open flowers at concentrations of 10, 20,50,100, or 200 g-liter-1 (1\%, 2\%, 5\%, 10\%, and 20\%), with distilled water as a control. All treatments, including the control, contained 50 mg DICA/liter to combat bacterial growth. FW and solution uptake were measured daily until the end of vase life.

The most effective continuous sucrose solutions, $2 \%$ and $5 \%$, were also applied to stems with immature buds. All solutions, including the distilled water control, contained $50 \mathrm{mg}$ DICA/ liter. Immature buds were defined as those buds with petals pointing downward on a vertical plane and lacking any red or yellow pigment. FW and solution uptake were measured daily until the end of vase life. The percentage of buds that completely opened and showed full coloration was also recorded.

Sucrose was administered to complete stems bearing open flowers and immature buds as a 24-h pulse at concentrations of $5 \%, 10 \%$, or $20 \%$, with distilled water as a control. Pulsing was conducted at $20 \mathrm{C}$. All treatments, including the control, contained $50 \mathrm{mg}$ DICA/liter to combat bacterial growth. After

Abbreviations: FW, fresh weight. 


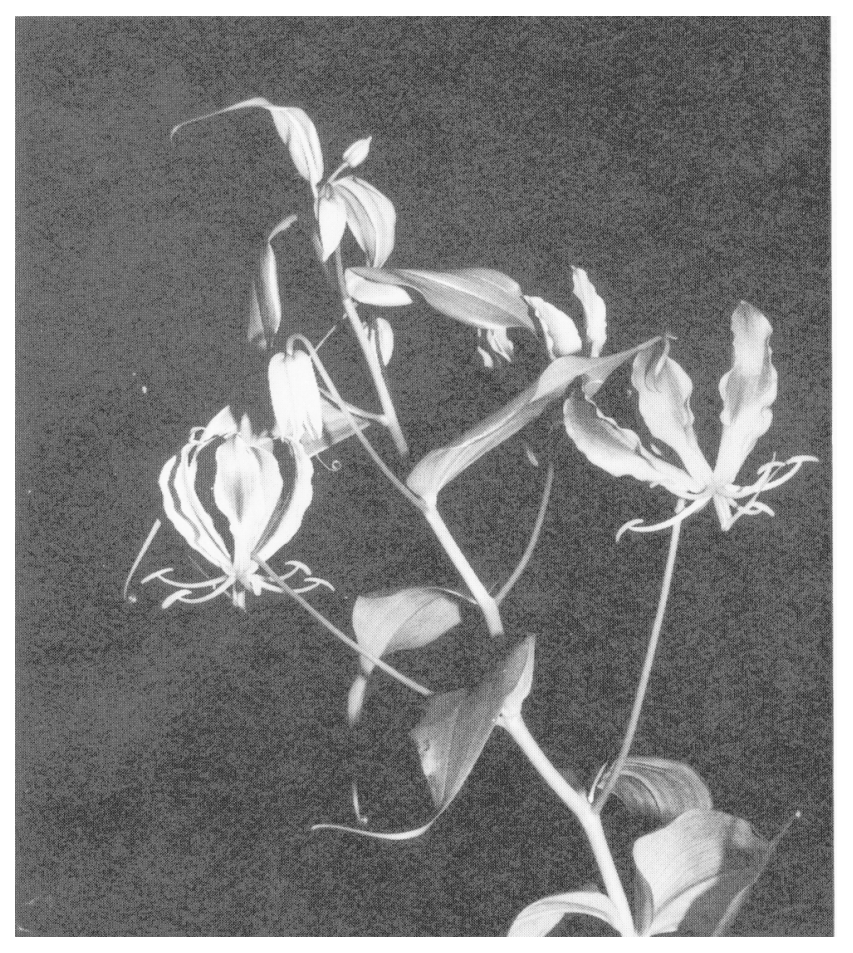

Fig. 1. Morphology of a complete stem of G. rothschildiana, showing" open flowers and immature buds.

pulsing, stems were placed in distilled water at $20 \mathrm{C}$ for vase life assessment.

Storage. Twelve complete stems, containing open flowers and immature buds, were placed in distilled water at $1 \pm 0.5 \mathrm{C}$ or $10 \pm \mathrm{lC}, 95 \% \mathrm{RH}$, and a light intensity of $5 \mu \mathrm{mol} \cdot \mathrm{m}^{-2} \cdot \mathrm{s}^{-1}$. Flower opening, color, and the condition of flowers, buds, and leaves were recorded daily.

-Sealed, air-filled polyethylene bags $(\approx 50 \mu \mathrm{m}$ thick $)$ are often used to reduce physical damage during transport. Bags containing complete stems with open flowers and immature buds were fitted with silicone septa, and gas samples were taken daily to measure the levels of $\mathrm{O}_{2}, \mathrm{CO}_{2}$, and ethylene. Oxygen and carbon dioxide samples were determined on a Shimadzu gas chromatography (model GC-8A) fitted with a TCD and a Shimadzu C-R3A integrator (Shimadzu Corp., Kyoto, Japan). Ethylene samples were determined using a Shimadzu GC-8A gas chromatography fitted with a FID and a Shimadzu C-R4A integrator.

Ethylene sensitivity. Ethylene sensitivity was assessed by incubating open flowers with $50 \mu$ ethylene/liter in $600-\mathrm{ml}$ preserving jars at 20C. Flowers were removed after $24 \mathrm{~h}$ and placed in distilled water at $20 \mathrm{C}$ for vase life determination. Control flowers were incubated for $24 \mathrm{~h}$ in sealed jars containing air. Gas samples indicated that ethylene levels from control stems remained $<0.5 \mu \mathrm{l} \cdot$ liter $^{-1}$.

\section{Results and Discussion}

Germicides. Of the five germicides tested, $5 \mathrm{mg}$ BCDMH/ liter and $50 \mathrm{mg} \mathrm{BChl} / \mathrm{liter}$ failed to significantly increase vase life of individual open flowers. The most effective germicides were 8-HQC (250 mg.liter $\left.{ }^{-1}\right)$, Physan-20 (50 mg.liter $\left.{ }^{-1}\right)$, and DICA $\left(50 \mathrm{mg} \cdot\right.$ liter $\left.^{-1}\right)$, all of which significantly increased vase life (by $=12 \%$ ) and maintained higher FW and solution uptake for 8 days after harvest compared with a distilled water control (Table 1). FW and solution uptake were measured 8 days after
Table 1. Effect of germicides on vase life, fresh weight (FW), and solution uptake in individual open $G$. rothschildiana flowers. FW and solution uptake are expressed as the percentage of initial FW (\% IW) and were measured 8 days after harvest. DICA, sodium dichloroisocyanurate; $\mathrm{BCDMH}$, 1-bromo-3-chloro-5,5-dimethylhydrantoin; 8-HQC, 8-hydroxyquinoline citrate; BChl, benzalkonium chloride. LSD at $P=0.05$.

\begin{tabular}{lrcccc}
\hline \hline $\begin{array}{l}\text { Germicide } \\
\begin{array}{l}\text { and concn } \\
(\mathrm{mg} \cdot \text { liter }\end{array}\end{array}$ & $\begin{array}{c}\text { Vase life } \\
(\text { days })\end{array}$ & $\begin{array}{c}\text { Stem } \\
\text { FW } \\
(\% \mathrm{IW})\end{array}$ & $\begin{array}{c}\text { Solution } \\
\text { uptake } \\
(\% \mathrm{IW})\end{array}$ & $\mathrm{pH}$ \\
\hline None & 0 & 8 & 77.6 & 4.8 & 6.9 \\
SDIC & 50 & 9 & 91.4 & -7.3 & 5.8 \\
B C D M H H & $5^{z}$ & 8 & 89.9 & 6.2 & 6.5 \\
8-HQC & 250 & 9 & 100.9 & 9.5 & 3.7 \\
BChl & 50 & 8 & 89.5 & 4.6 & 5.3 \\
Physan & 50 & 9 & 85.9 & 7.6 & 5.6 \\
LSD & ---- & 1 & 9.6 & 2.3 & --- \\
\hline
\end{tabular}

${ }^{2}$ Quantity refers to available chlorine.

Table 2. Effect of continuous presence of sucrose solutions on vase life, FW, and solution uptake in individual open G. rothschildiana flowers. FW and solution uptake are expressed as the percentage of initial FW (\% IW) and were measured 8 days after harvest. All solutions contained $50 \mathrm{mg}$ DICA/liter. LSD at $P=0.05$.

\begin{tabular}{cccc}
\hline \hline $\begin{array}{c}\text { Sucrose } \\
(\%)\end{array}$ & $\begin{array}{c}\text { Vase life } \\
\text { (days) }\end{array}$ & $\begin{array}{c}\text { Stem FW } \\
\text { at day } 8 \\
(\% \text { IW })\end{array}$ & $\begin{array}{c}\text { Solution } \\
\text { uptake } \\
\text { at day 8 } \\
(\% \text { IW })\end{array}$ \\
\hline 0 & 8 & 94.8 & 6.0 \\
1 & 9 & 92.7 & 4.9 \\
2 & 9 & 98.9 & 8.4 \\
5 & 9 & 99.3 & 8.1 \\
10 & 9 & 83.2 & 5.0 \\
LSD & 1 & 9.6 & 2.9 \\
\hline
\end{tabular}

harvest as this corresponded to the end of vase life in control stems treated with distilled water.

Variations in $\mathrm{pH}$ of the germicides tested may partially explain improved solution uptake (Table 1). Lowest $\mathrm{pH}$ was recorded for $250 \mathrm{mg} 8$-HQC/liter, the germicide solution resulting in the highest increase in FW and solution uptake, whereas the least effective germicide, $\mathrm{BCDMH}$, recorded the highest $\mathrm{pH}$, next to the control. An acidic $\mathrm{pH}$ of $\approx 3.5$ is known to improve solution uptake (Halevy and Mayak, 1981).

The addition of germicides to vase solutions at the concentrations used in this study is well known to improve vase life in a range of cut flowers (Halevy and Mayak, 1981; Kofranek et al., 1974; Larsen and Scholes, 1966). DICA (50 mg.liter ${ }^{-1}$ ), chosen for its ready local availability, was thereafter routinely added to all sucrose solutions.

Sucrose treatments. Continuous application of $1 \%, 2 \%$, or $5 \%$ sucrose to individual open flowers significantly enhanced vase life (by $=12 \%$; Table 2 ). Flowers treated with sucrose maintained similar solution uptake rates and FW compared with controls placed in distilled water (Table 2), indicating that sucrose did not extend vase life by improving solution uptake but by delaying senescence in the flowers. The exception was $10 \%$ sucrose, which significantly reduced FW.

FW was significantly increased in immature buds placed in $2 \%$ or $5 \%$ sucrose (Fig. 2), associated with more complete flower development than seen in buds placed in distilled water. Sucrose treatment also significantly enhanced opening and coloration of immature buds, resulting in a longer vase life (Table 3 ). In contrast, FW and solution uptake did not improve significantly 


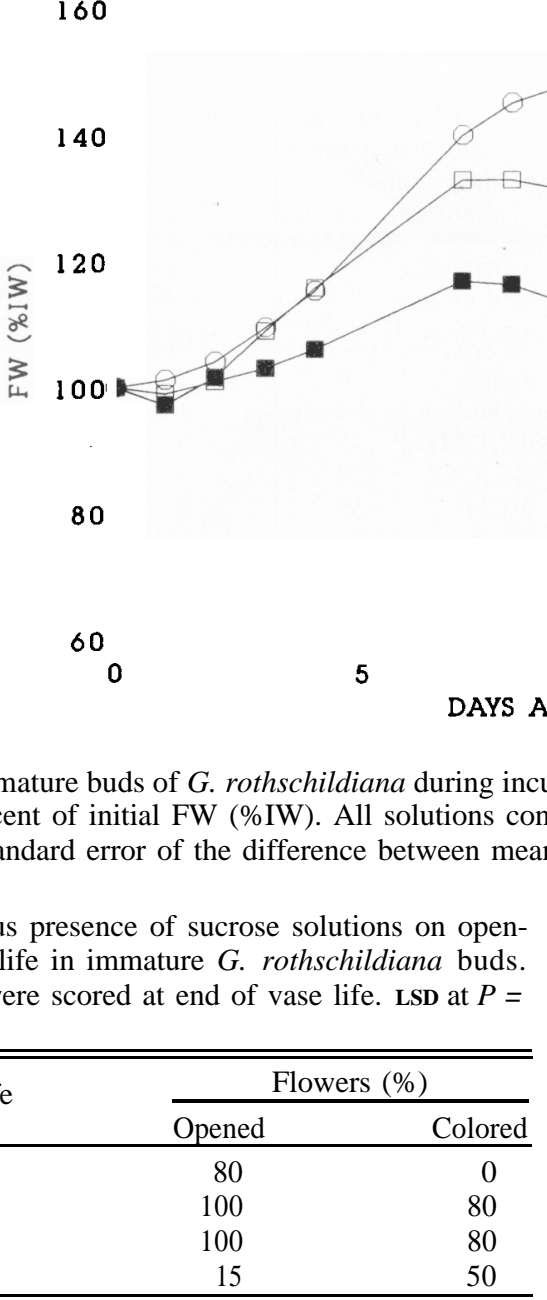

Table 4. Effect of a 24-h sucrose pulse on vase life, FW, and solution uptake in complete G. rothschildiana stems. FW and solution uptake are expressed as the percentage of initial FW (\%IW) and were measured 8 days after harvest. All solutions contained $50 \mathrm{mg}$ DICA/ liter. LSD at $P=0.05$.

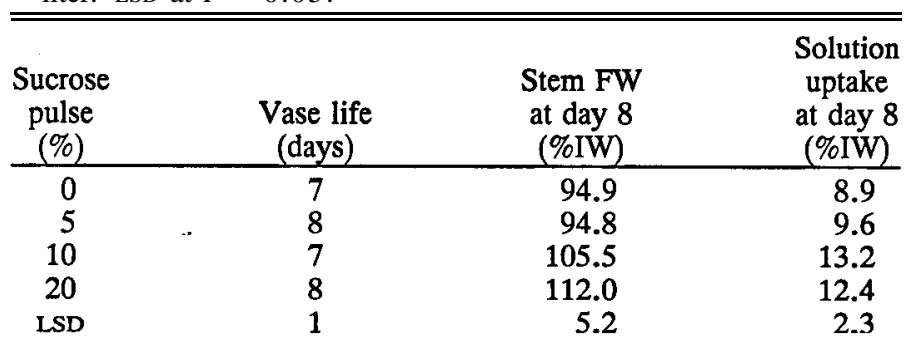

in open flowers (Table 2), as opening and coloration had already proceeded. Immature buds placed in distilled water containing $50 \mathrm{mg}$ DICA/liter did not fully develop and became stunted and curled and remained green. Concentrations of sucrose $>5 \%$ did not improve development of immature buds (data not shown). Sucrose is known to aid the development of buds in many cutflower varieties (Kofranek and Halevy, 1972; Kofranek et al., 1975).

In complete stems, a 24 -h pulse with $20 \%$ sucrose significantly enhanced vase life (by $\approx 14 \%$; Table 4 ). The effects of the 24-h pulse were still visible 8 days after harvest in the significantly higher FW and solution uptake rates. Addition of sucrose, either as a pulse of continuous treatment, significantly extended vase life in $G$. rothschildiana by improving solution uptake and delaying senescence in fully developed flowers (Table 4) and enhancing the development of immature buds (Table 3). Exogenous sucrose, therefore, improved the osmotic potential of flowers, as well as promoting bud development (Halevy, 1976), and is thought to replace depleted carbohydrate reserves in cut flowers, thereby maintaining metabolic activity (Coorts, 1973; Ho and Nichols, 1977).

Storage. Previous publications on the postharvest care of G. rothschildiana suggest storing stems at 1C (Sacalis, 1989; Vaughan, 1988). Those stems stored in water at $1 \mathrm{C}$ in our trials developed chilling injury, with black leaves, stems, and flowers within 3 days (Fig. 3). These symptoms were not evident in stems stored at 10C for 10 days (data not shown). We therefore recommend that $G$. rothschildiana stems be stored at 10C if short-term storage is necessary. Vase life of stems stored at 10C was not significantly lower than that of fresh material (data not shown).

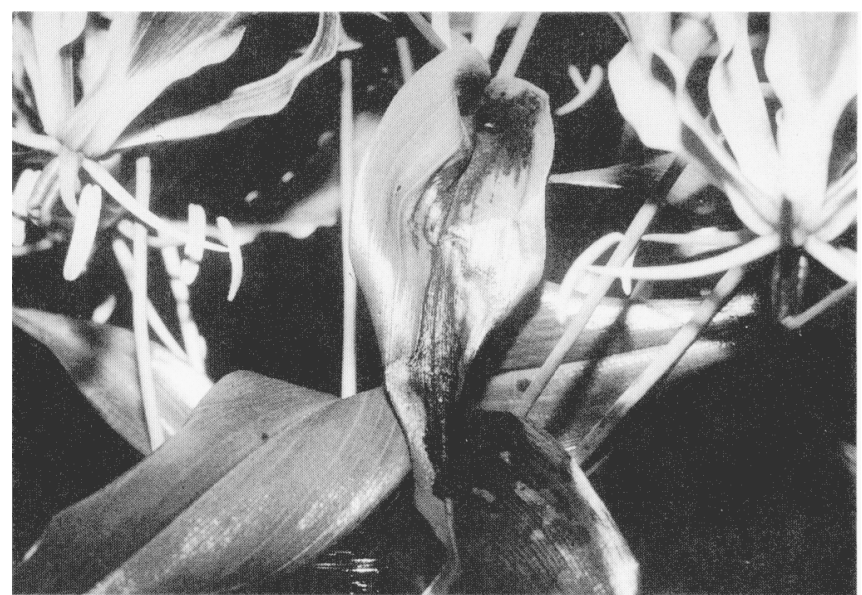

Fig. 3. Chilling injury in $G$. rothschildiana stored at $1 \mathrm{C}$ for three days. Symptoms of chilling injury include black necrotic areas on leaves, stems, and flowers. 
Ethylene sensitivity. Gloriosa rothschildiana is often packed and transported in air-filled plastic bags to minimize physical damage (Vaughan, 1988). Gas analysis revealed that ethylene levels within sealed bags held at $20 \mathrm{C}$ rose from $\approx 0.02 \mu \mathrm{l} \cdot$ liter $^{-1}$ to $0.3 \mu \mathrm{l} \cdot$ liter $^{-1}$ within 8 days (Fig. 4). This relatively sharp increase in ethylene levels corresponded to the first signs of fungal infection. Infection with Botrytis cinerea Pers. ex Fr. resulted in a substantial increase in ethylene production in rose and carnation flowers (Elad, 1988).

Exposure of G. rothschildiana to $50 \mu \mathrm{l}$ ethylene/liter for 24 $\mathrm{h}$ had no effect on vase life (data not shown). The levels of, ethylene recorded in the air-filled bags, therefore, probably would have had no adverse effect on $G$. rothschildiana stems.

Carbon dioxide levels in sealed bags rose from $\approx 1 \%$ to $4 \%$, while oxygen levels decreased from $20 \%$ to $9 \%$, indicating some modification in atmosphere. Based on experience with other cutflower crops, we consider the levels of $\mathrm{CO}_{2}$ and $\mathrm{O}_{2}$ were not high or low enough, respectively, to influence respiration and vase life (Staby, 1977).

Vase life was terminated in stems that had been kept in airfilled bags at $20 \mathrm{C}$ because of fungal infection, identified as $B$. cinerea. Vase life of stems removed from the air-filled bags after 9 days of storage was poor, ranging from 1 to 3 days (data not shown). Poor vase life was attributed mainly to fungal in-

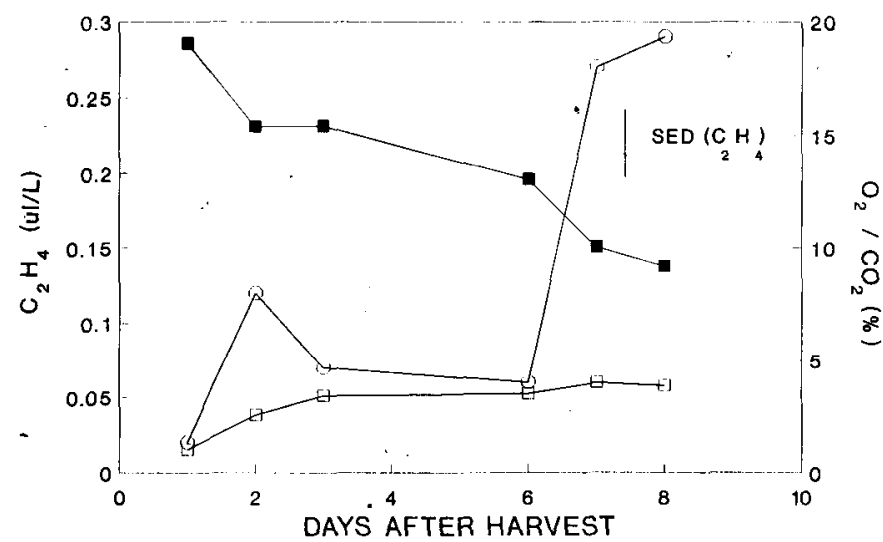

Fig. 4. Changes in concentration of $\mathrm{O}_{2}(\boldsymbol{\square}), \mathrm{CO}_{2}(\square)$, and ethylene (0) during storage of complete $G$. rothschildiana stems in air-tight plastic bags at 20C. Arrows indicate the end of vase life. SE values for $\mathrm{O}_{2}$ and $\mathrm{CO}_{2}$ do not exceed the size of the data symbols and are not shown. fection. We recommend that stems be kept in air-filled bags for no longer than 6 days, as fungal infections became apparent after 7 days.

From this study we recommend: 1) postharvest treatment of individual flowers of $G$. rothschildiana with a solution containing a germicide (preferably $50 \mathrm{mg}$ DICA or $250 \mathrm{mg} 8-\mathrm{HQC} /$ liter), and between $2 \%$ and 5\% sucrose. 2) Alternatively, complete stems may be pulsed for $24 \mathrm{~h}$ in a solution containing $20 \%$ sucrose and $50 \mathrm{mg}$ DICA/liter to aid in the development of immature buds. 3) Stems may be stored in water for up to 10 days at 10C, or for no more than 6 days in sealed, air-filled bags at 20C. Stems should never be placed at 1C. Gloriosa rothschildiana is not sensitive to ethylene levels up to $50 \mu l \cdot$ liter $^{-1}$.

\section{Literature Cited}

Coorts, G.D. 1973. Internal metabolic changes in cut flowers. HortScience 8:195-198.

Elad, Y. 1988. Involvement of ethylene in the disease caused by Botrytis cinerea on rose and carnation flowers and the possibility of control. Ann. Applied Biol. 113:589-598.

Halevy, A.H. 1976. Treatments to improve water balance of cut flowers. Acts Hort. 64:223-226.

Halevy, A.H. and S. Mayak. 1981. Senescence and post-harvest physiology of cut flowers-Part 2. Hort. Rev. 3:59-143.

Ho, L.C. and R. Nichols. 1977. Translocation of ${ }^{14} \mathrm{C}$-sucrose in relation to changes in carbohydrate content in rose corollas cut at different stages of development. Ann. Bet. 41:227-242.

Holstead, K.L. 1985. Exotics: Handle with care. Florists' Rev. (10 Oct.):16-20.

Kofranek, A.M. and A.H. Halevy. 1972. Conditions for opening cut chrysanthemum flower buds. J. Amer. Soc. Hort. Sci. 97:578-584.

Kofranek, A. M., A.H. Halevy, and J. Kubota. 1975. Bud opening of chrysanthemums after long term storage. HortScience 10:378-380.

Kofranek, A. M., H.C. Kohl, and J. Kubota. 1974. A slow-release chlorine compound as a vase water additive. Florists' Rev. 154(4000):21,63-65.

Larsen, F.E. and J.F. Scholes. 1966. Effects of 8-hydroxyquinoline citrate, N-dimethyl amino succinamic acid, and sucrose on vase life and spike characteristics of cut snapdragons. Proc. Amer. Soc. Hort. Sci. 89:694-701.

Sacalis, J.N. 1989. Fresh (cut) flowers for designs. Postproduction Guide 1. D.C. Kiplinger Chair in Floriculture, The Ohio State. Univ.

Staby, G.L. 1977. Controlled atmosphere and low pressure storage of floral crops-overview. Proc. 2nd Natl. Controlled Atmosphere Res. Conf., Apr. 1977, Michigan State Univ, p. 60-70.

Vaughan, M.J. 1988. The complete book of cut flower care. Timber Press, Portland, Ore. 